\title{
STRUCTURAL EQUATION MODELING (SEM) OF PERFORMANCE EVALUATION INDICES IN GENERAL DIRECTORATE OF YOUTH AND SPORT OF GUILAN PROVINCE WITH PARTIAL LEAST SQUARES (PLS) \\ Hamidreza Goharrostami ${ }^{1}$, Mustafa Mollaei Nejad*1 ${ }^{*}$ Rahim Ramezani Nejad $^{3}$ \\ ${ }^{1}$ Assistant Professor, Faculty of Physical Education, University of Guilan, Iran. ${ }^{2}$ M.A. Strategic Management of Sport Organizations at the University of Guilan, Iran. \\ ${ }^{3}$ Professor, Faculty of Physical Education, University of Guilan, Iran.
}

\begin{abstract}
Purpose: to evaluate the performance evaluation the indexes of general directorate of youth and sport of Guilan province by using the BSC approach. Material: This was a descriptive and field -based survey. The population included managers and experts from the general directorate of youth and sport of Guilan province. The purposive sampling was used. A questionnaire was used to collect data. Content validity and reliability were approved by experts Cronbach's alpha test (0.89) respectively. For data analyzing and model fitting the structural equation modeling (SEM) with PLS software was used. Results: performance evaluation model of general directorate of youth and sport of Guilan province has four factors, 12 dimensions and 55 indicators. So that learning and development factor has 4 dimensions and 13 indicators, internal processes have 4 dimensions and 23 indicators, financial factor has 2 dimensions and 7 indicators and customer and sport results have 2 dimensions 12 indicators. Internal processes, customer and sporting results, learning and development and financial factors had coefficients of factor loading of $0.91,0.83,0.81$ and 0.80 respectively. Conclusion: We concluded that, in evaluating the performance of the organization, special attention should be paid on four studied terms and their confirmed dimensions and indicators. Based on the factor loading priority of activities and evaluation should be allocated to internal processes, customer and sporting results, learning and development and financial factors. So this index can be used to design a model to evaluate the performance of the general directorate of youth and sport of Guilan province.
\end{abstract}

Keywords: balanced, scorecard, index, performance, evaluation.

\section{Introduction}

The function of continuous monitoring, identifying items and affecting factors on the function of organizational performance in manufacturing and servicing industries for a few decades has clearly shown its significance and owners of various industries are well aware about the key role of continuous oversight on the key points of performance [1].

Monitoring and evaluation of performance can make the service intelligent and can be considered as the main section of the development and organizational implementation of policy and can be very helpful in pushing the system toward the optimum use of resources [5]. All public and private organizations, for the development, growth and sustainability in today's competitive arena are in need of performance evaluation systems, through which be able to measure the efficiency and effectiveness of the programs of organizations, process and human resources. Efficient organizations do not suffice to simply gather and analyze data, they also use this data to improve their organization and achieve the mission and strategies. In other words, instead of evaluating the appraisal performance they consider the performance of management [4].

Performance evaluation is a process that seems to be essential in all organizations and this evaluation is in fact a form of hedging against pests ahead [18]. On the other hand, in evaluating the performance of sport organizations, there are always problems that make the accurate and reliable assessment almost impossible. There are a lot of criteria and indicators and many hidden cases which have made assessment as a complex issue in a way that even mathematical algorithms fail to provide an appropriate solution to build an efficient evaluation model [7]. Kaplan and Norton (2006) in the late twentieth century presented a tool to evaluate the performance of the organizations known as the Balanced Scorecard (BSC). These tools then evolved beyond an assessment tool and provided a framework for the implementation of the overall goals and strategies of organization [16]. Nowadays in the sport organizations of the country different models are used to evaluate the performance that each of them has a different approach to the context. One of these strategic models is the Balanced Scorecard where all aspects of an organization are checked equally [13]. In this study in order to evaluate the performance among the various presented models Balanced Scorecard was selected. This model, with a focus on four key aspects of development and learning, internal processes, customer and financial factors provided the needed criteria and indicators to evaluate the performance of the organization [4]. In order to perform the duties of the ministry of

(c) Hamidreza Goharrostami, Mustafa Mollaei Nejad,

Rahim Ramezani Nejad, 2016

doi:10.15561/20755279.2016.0507 
sport and youth in the provinces, the provincial departments of youth and sport is formed on the basis of the statute of the ministry of sport and youth. General department of youth and sport is an organization that is created in order to provide a favorable context for the development of professional sport, sport and community, cultural, education and research, organizing youth affairs, legal, parliamentary and provincial coordination, resource development and support and related public relations and motivating and attracting people to the sport and discover talents and raising the level of skills sport on the basis of the predicted principles and objectives of the federation and physical education organization.

This general department works under the organizational chart of the ministry of youth and sport and indeed is the representative and vicar of the ministry of youth and sport in the province that monitors the related activities in the province in coordination with the ministry of sport and with full respect of the relevant laws and regulations [2]. In this regard some researches have been done, e.g. Hosseini (2011), in his study indicated that the financial and economic indicators had the greatest effect on performance of clubs and clubs to improve the performance, need to manage costs and create ways to increase their income, in addition, the stability of the players, management and club coaches had special significance in this study [8]. Saadatpour (2011), in a study evaluated the performance of staff in physical education offices of Khorasan Razavi province based on the Balanced Scorecard (BSC) and indicated that the importance of customer and financial areas is desirable but is not desirable in the case of internal processes, learning and development. His study also revealed that four aspects of balanced scorecard will not be equally important [19]. Mir Fakhredini et al (2012), in their study revealed that the department of physical education in Yazd province in both internal processes and learning and development had optimal performance and in both customer and financial factors (BSC) did not [14]. Alian (2013), in his study showed that the performance of the internal infrastructures of general directorate of youth and sport within Isfahan province based on the Balanced Scorecard (BSC) and its performance in terms of the effect of financial system, customers, internal processes, learning and continuous learning in the establishment of evaluation based on the Balanced Scorecard method was significantly lower than the average [2]. Mosaffa (2014), in his research found that in the sport model designed for the sport boards of Guilan Province internal processes have the highest importance and financial factor has the least importance [15]. ZhengMin et al (2005) in their study entitled the Balanced Scorecard performance management found that four (BSC) factors were not the main source of supplying strategic plan but as a method of performance management can be used for different purposes by different stakeholders. Therefore, any changes required at (BSC) can be achieved based on the proposed assumptions and follows the long-term strategic success of organization. Delaney (2008) during his study concluded that when university conducted the performance evaluation system in the sport section of university by the use of Balanced Scorecard it had 3 goals in operating financial, customer and learning and development factors and 4 goals at the internal processes through which the profitability of this segment and the tendency of students toward sportive activities, particularly competitive ones increased [6]. Alonso and Fernandez (2009) in a study investigated the effect of Balanced Scorecard on public investment in the field of sport and concluded that the performance indicators are the reason for the appropriateness, effectiveness, efficiency and durability [3]. O'Boyle (2015) in a study stated that organizational performance is an essential management function in the field of non-profit sport to increase the pressure on these organizations to provide high-quality services to stakeholders in an accountable and transparent manner [17]. So given that the performance evaluation of the departments of youth and sport is one of the first and most basic part of strategic planning, the researcher attempts to analyze the performance evaluation indicators of general directorate of youth and sport in Guilan province by the use of Balanced Scorecard so that by using these indicators and designed models can evaluate the organization's performance.

\section{Methodology}

This study was a descriptive-survey that was conducted within a field study and to explain the theoretical foundations of performance evaluation criteria of general directorate of youth and sport of guilan province, the available resources (reports, websites and documents) were used. In this regard, in order to clarify and enrich the study provided information used to identify the criteria and options to evaluate the performance of the general directorate of youth and sport, interviews were organized with some managers and experts from the general directorate of youth and sport, faculty members and professors and inaddtion to reviewing criteria and identified options, collecting and summarizing the results, four aspects of the balanced scorecard, 12 dimensions and 60 indexes were determined for the design of performance evaluation system in general directorate of youth and sport of Guilan province.

The studied population consisted of all managers and deputy director of the general directorate of youth and sport of Guilan province $(\mathrm{n}=80)$ who through purposeful or qualitative sampling were chosen as statestical sample. So a total of 80 questionnaires were distributed and 64 questionnaires were usable and 16 questionnaires were flawed. To collect the data a research made questionnaire (significance criterion) was used to determine the importance of each indicators in the evaluation of performance. To determine the validity and resolve possible ambiguities, questionnaire was studied by a group of professors and faculty members of sport management group 
in Guilan University and after making the necessary corrections, the questionnaires were distributed among the samples. The (AVE) criterion for desirableness is equal to or higher than 5.0 which in this study, the amount for all structures is above 0.5 . In order to determine the reliability of the questionnaire Cronbach Alpha was used $(\alpha=$ 0.89 ). In this study, structural equation modeling (SEM) and partial least squares method using Smart PLS software for data analysis and model fitting and in descriptive statistics SPSS23was used.

\section{Findings}

The findings were divided into two parts. The first part by the use of data obtained from the questionnaire and second part through descriptive statistical techniques tried to analyze the quantitative data. Results indicated that the questionnaire respondents in terms of gender were $68 \%$ men and $32 \%$ female. In terms of educational level $42 \%$ of respondents had B.A., 36\% had M.A., 14\% had associate's degree $14 \%, 6 \%$ had Ph.D. and $2 \%$ had diploma. Work experience of respondents also included 15 years and older (42\%), 10.6 years (27\%), 15-11 years $(19 \%)$ and less than 5 years $(12 \%)$, respectively.

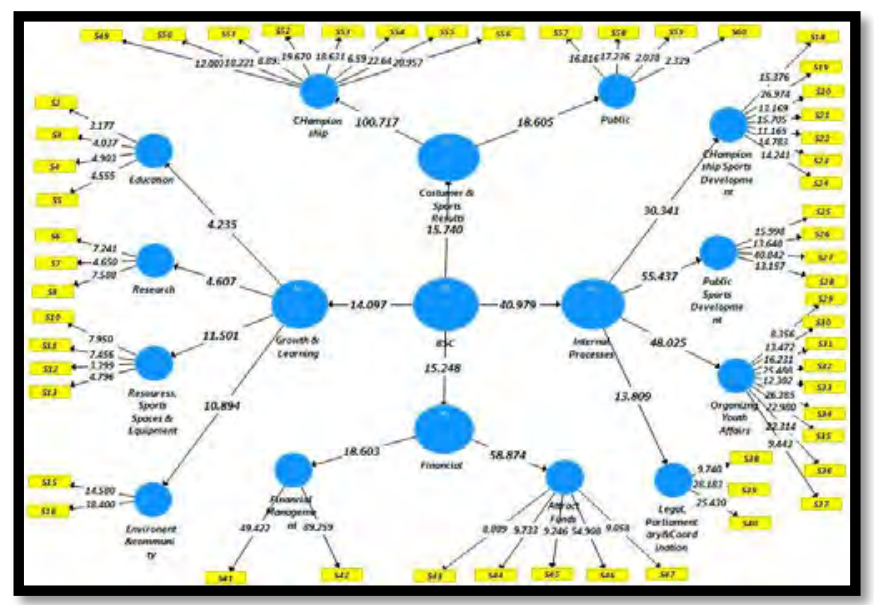

Figure1. The pattern of significant coefficients $(z)$

The second part included the analysis of the data using PLS model by the use of three measurements (validity, convergent reliability, divergent validity), structural model (correlation coefficient, determining coefficient and prediction coefficient) and general model (GOF criterion); that all these factors, approved and properly reported. After data analysis software output was given in Figures (1) and (2). To assess the significance of causal relationships between variables partial index of $t$ value was used. Based on the significance level of 0.05 $\mathrm{t}$ value must be greater than 1.9 for less than this amount, the parameters of the model is not considered important. After determining the significance of relationships between variables standardized coefficients of related hypotheses investigated, Figure (2) shows the model with factor loadings; and at the end for overall fit of the research model GOF criterion was used that its output is given in the next section.

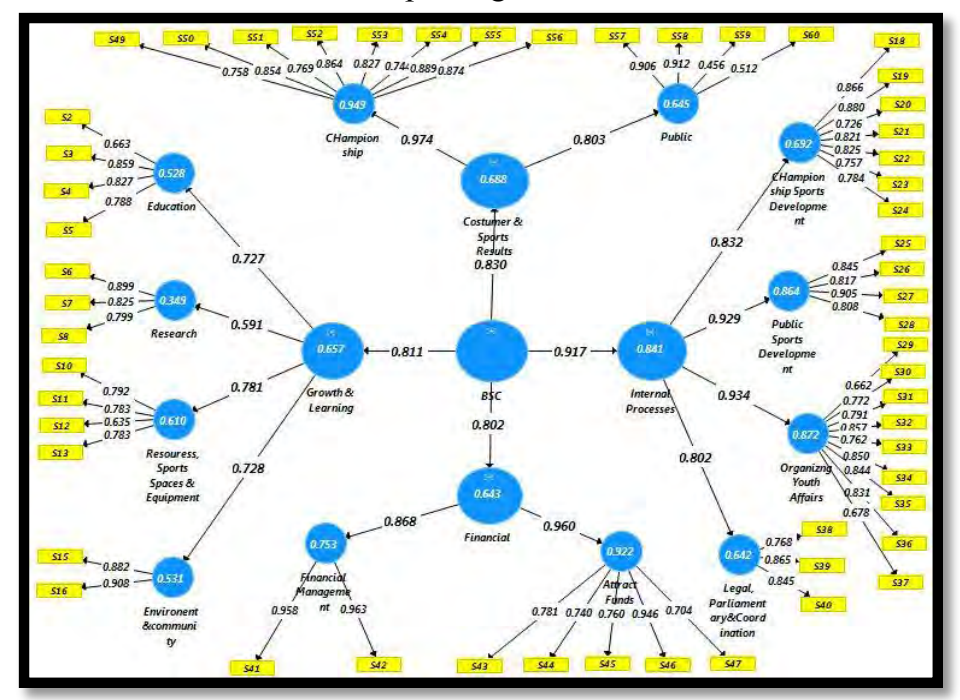

Figure2. The pattern of the values of factor loadings coefficients 
Following the GOF criterion was used for overall fit of the model that calculated by the following formula:

$\mathrm{GOF}=\sqrt{\overline{\text { communalitles }} \times \bar{R}^{2}}$

$\mathrm{GOF}=\sqrt{\text { communalitles }} \times \bar{R}^{2}=\sqrt{0.56 \times 0.70}=0 / 65$

$\overline{\text { communalitles }}=\frac{0.63+0.60+0.52+0.50}{4}=0.56 \mathrm{R}^{2}=\frac{0.65+0.84+0.64+0.68}{4}=0.70$

Regarding the three values of $0.01,0.25$ and 0.36 as weak, medium and strong values for this criterion, the value of $0 / 65$ indicates strong overall fit of the model.

Table 1 - coefficients of factor loadings

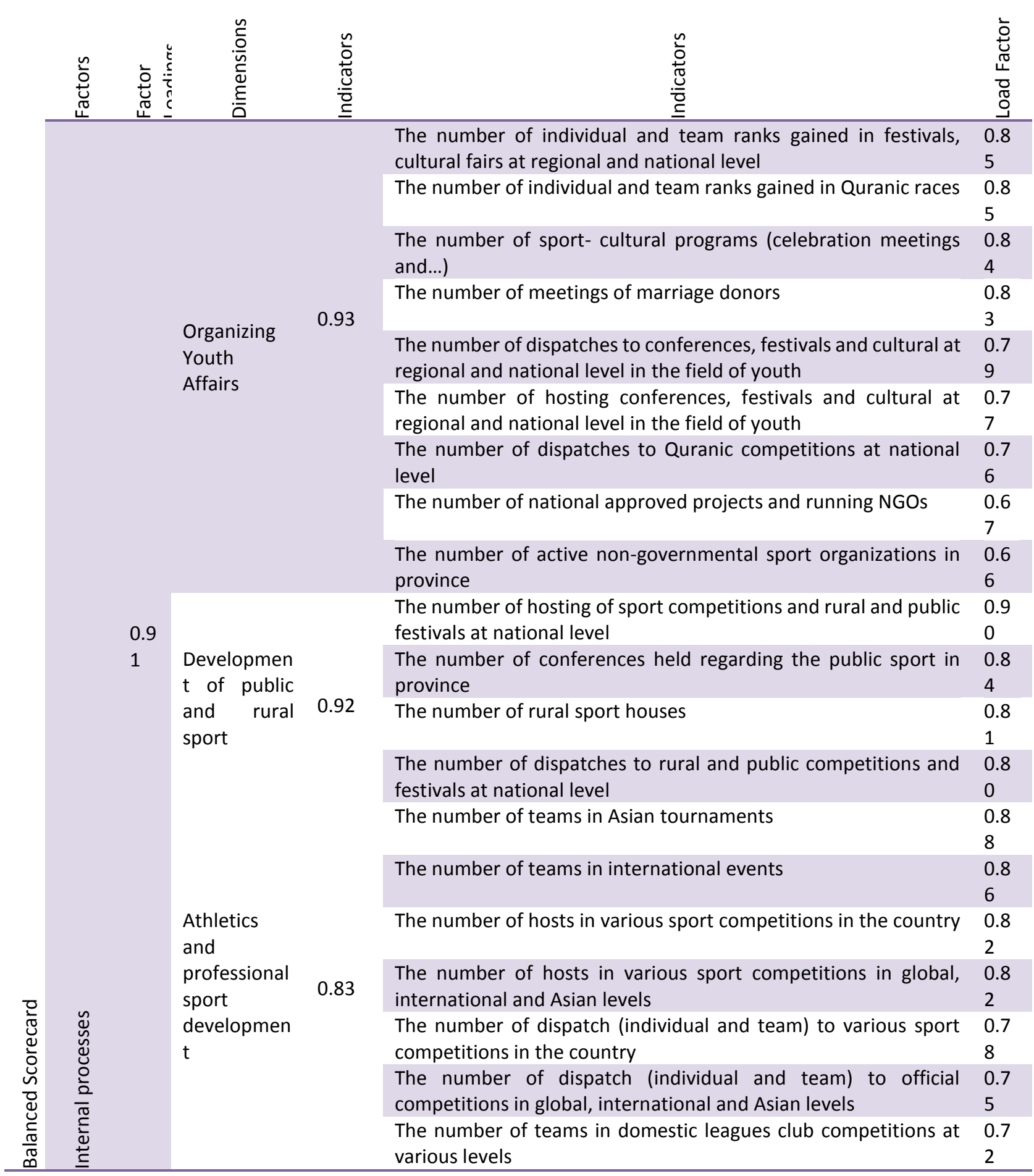




\begin{tabular}{|c|c|c|c|c|c|}
\hline & & \multirow{3}{*}{$\begin{array}{l}\text { Legal, } \\
\text { parliamenta } \\
\text { ry and } \\
\text { coordinatio } \\
\mathrm{n}\end{array}$} & \multirow{3}{*}{0.80} & \multirow{2}{*}{$\begin{array}{l}\text { The number of estates resolved with the use of non-budgetary } \\
\text { priority } \\
\text { The number of annual performance appraisal of the departments } \\
\text { of Youth and Sport in province }\end{array}$} & $\begin{array}{l}0.8 \\
6\end{array}$ \\
\hline & & & & & $\begin{array}{l}0.8 \\
4\end{array}$ \\
\hline & & & & $\begin{array}{l}\text { The number of establishment licenses and constructed sport } \\
\text { clubs }\end{array}$ & $\begin{array}{l}0.7 \\
6\end{array}$ \\
\hline \multirow{10}{*}{ 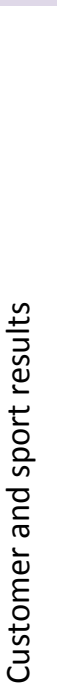 } & \multirow{10}{*}{$\begin{array}{l}0.8 \\
3\end{array}$} & \multirow{10}{*}{$\begin{array}{l}\text { Results of } \\
\text { athletics and } \\
\text { professional } \\
\text { sport }\end{array}$} & \multirow{10}{*}{0.97} & The number of shares acquired in Olympics & 0.8 \\
\hline & & & & & 8 \\
\hline & & & & $\begin{array}{l}\text { The number of individual and team ranks gained in festivals, } \\
\text { cultural fairs at regional and national level }\end{array}$ & $\begin{array}{l}0.8 \\
7\end{array}$ \\
\hline & & & & The number of individual and team ranks gained in Quranic races & 0.8 \\
\hline & & & & & 6 \\
\hline & & & & $\begin{array}{l}\text { The number of sport- cultural programs (celebration meetings } \\
\text { and...) }\end{array}$ & $\begin{array}{l}0.8 \\
5\end{array}$ \\
\hline & & & & The number of meetings of marriage donors & $\begin{array}{l}0.8 \\
2\end{array}$ \\
\hline & & & & $\begin{array}{l}\text { The number of dispatches to conferences, festivals and cultural at } \\
\text { regional and national level in the field of youth }\end{array}$ & $\begin{array}{l}0.7 \\
6\end{array}$ \\
\hline & & & & $\begin{array}{l}\text { The number of hosting conferences, festivals and cultural at } \\
\text { regional and national level in the field of youth }\end{array}$ & $\begin{array}{l}0.7 \\
5\end{array}$ \\
\hline & & & & $\begin{array}{l}\text { The number of dispatches to Quranic competitions at national } \\
\text { level }\end{array}$ & $\begin{array}{l}0.7 \\
4\end{array}$ \\
\hline
\end{tabular}

Table 1 - coefficients of factor loadings

\begin{tabular}{|c|c|c|c|c|c|}
\hline 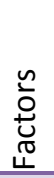 & 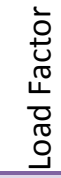 & 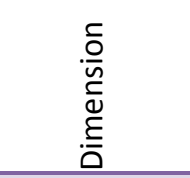 & 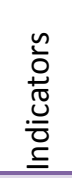 & 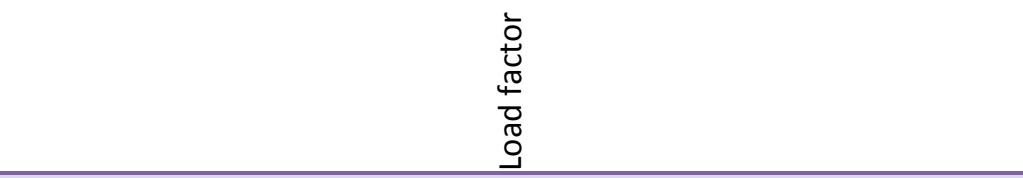 & 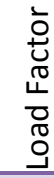 \\
\hline \multirow{8}{*}{ 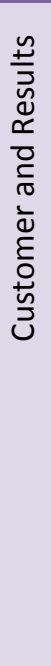 } & & \multirow{5}{*}{$\begin{array}{l}\text { Results of } \\
\text { public and } \\
\text { rural sport }\end{array}$} & \multirow{5}{*}{$\begin{array}{l}0.8 \\
0\end{array}$} & $\begin{array}{l}\text { The number of individual and team ranks gained in competitions and } \\
\text { festivals, rural and public sport at the country level }\end{array}$ & $\begin{array}{l}0.9 \\
1\end{array}$ \\
\hline & & & & $\begin{array}{l}\text { The number of individual and team ranks gained in competitions and } \\
\text { festivals, rural and public sport at international level }\end{array}$ & $\begin{array}{l}0.9 \\
0\end{array}$ \\
\hline & & & & The committee of women's organized sport insurance & $\begin{array}{l}0.5 \\
1\end{array}$ \\
\hline & & & & The committee of men's organized sport insurance & $\begin{array}{l}0.4 \\
5\end{array}$ \\
\hline & & & & Indoor sport space per capita (ratio of area to population) & 0.7 \\
\hline & & $\begin{array}{l}\text { Resources, } \\
\text { sport }\end{array}$ & & Outdoor space per capita (ratio of area to population) & $\begin{array}{l}0.7 \\
8\end{array}$ \\
\hline & & equipment & $\begin{array}{l}0.7 \\
8\end{array}$ & The number of active male and female referees & $\begin{array}{l}0.7 \\
8\end{array}$ \\
\hline & & 3 & & The number of active male and female coaches & $\begin{array}{l}0.6 \\
3\end{array}$ \\
\hline \multirow{5}{*}{ 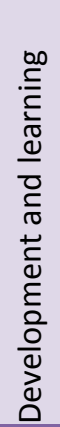 } & \multirow{5}{*}{$\begin{array}{l}0.8 \\
1\end{array}$} & $\begin{array}{l}\text { Environme } \\
\text { nt and }\end{array}$ & 0.7 & $\begin{array}{l}\text { The number of agreements with other organizations in the field of } \\
\text { championship, professional, public and educational sports }\end{array}$ & $\begin{array}{l}0.9 \\
0\end{array}$ \\
\hline & & $\begin{array}{l}\text { Communit } \\
\text { y }\end{array}$ & 2 & $\begin{array}{l}\text { The number of provincial experts in charge of general department in } \\
\text { federations and national organizations }\end{array}$ & $\begin{array}{l}0.8 \\
8\end{array}$ \\
\hline & & & & $\begin{array}{l}\text { The number of arbitration courses held at national and international } \\
\text { level in the province }\end{array}$ & $\begin{array}{l}0.8 \\
5\end{array}$ \\
\hline & & Education & 0.7 & $\begin{array}{l}\text { The number of people assigned to coaching courses at national and } \\
\text { international level }\end{array}$ & $\begin{array}{l}0.8 \\
2\end{array}$ \\
\hline & & & 2 & $\begin{array}{l}\text { The number of people dispatched to arbitration enhancement courses } \\
\text { at the country and international levels }\end{array}$ & $\begin{array}{l}0.7 \\
8\end{array}$ \\
\hline
\end{tabular}




\begin{tabular}{|c|c|c|c|c|c|}
\hline & & \multirow{4}{*}{ Research } & \multirow{4}{*}{$\begin{array}{l}0.5 \\
9\end{array}$} & $\begin{array}{l}\text { The number of coaching courses held in national and international level } \\
\text { in the province }\end{array}$ & $\begin{array}{l}0.6 \\
6\end{array}$ \\
\hline & & & & $\begin{array}{l}\text { The number of executive- scientific meetings (such as academic } \\
\text { meetings and the general department) }\end{array}$ & $\begin{array}{l}0.8 \\
9\end{array}$ \\
\hline & & & & $\begin{array}{l}\text { Number of research - sport projects taking place in the province in the } \\
\text { form of Master and Ph.D. thesis }\end{array}$ & $\begin{array}{l}0.8 \\
2\end{array}$ \\
\hline & & & & $\begin{array}{l}\text { The number of scientific papers in seminars and congresses in interior } \\
\text { and exterior levels }\end{array}$ & $\begin{array}{l}0.7 \\
9\end{array}$ \\
\hline \multirow{10}{*}{ 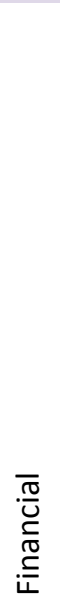 } & \multirow{10}{*}{$\begin{array}{l}0.8 \\
0\end{array}$} & \multirow{8}{*}{$\begin{array}{l}\text { Absorption } \\
\text { of financial } \\
\text { resources }\end{array}$} & \multirow{8}{*}{$\begin{array}{l}0.9 \\
6\end{array}$} & The provincial absorption of credit from other sources (cost, capital) & $\begin{array}{l}0.9 \\
4\end{array}$ \\
\hline & & & & The absorption of financial resources through donors & $\begin{array}{l}0.7 \\
8\end{array}$ \\
\hline & & & & The revenue from the ads and... & 0.7 \\
\hline & & & & & 6 \\
\hline & & & & The amount of income from the rent of properties & 0.7 \\
\hline & & & & & 4 \\
\hline & & & & The amount of income from the sale of properties & 0.7 \\
\hline & & & & & 0 \\
\hline & & \multirow{2}{*}{$\begin{array}{l}\text { Financial } \\
\text { Manageme } \\
\text { nt }\end{array}$} & \multirow{2}{*}{$\begin{array}{l}0.8 \\
6\end{array}$} & Cost budget of the department of sport and youth & $\begin{array}{l}0.9 \\
6\end{array}$ \\
\hline & & & & Constructional budget of the department of sport and youth & $\begin{array}{l}0.9 \\
5\end{array}$ \\
\hline
\end{tabular}

\section{Discussion and Conclusion}

One of the managerial problems in the world is that the value creation of organizations has been changed but their performance evaluation tools have not been changed. This is why determining the appropriate model for assessing organizational performance is considered as one of the basic principles of the organization to develop and progress [11]. To this end the purpose of this study is to provide a structural equation modeling (SEM) for the performance evaluation indexes in general directorate of youth and sport of Guilan province through balanced scorecard approach which was done by reviewing the opinions of elected members of the general directorate of youth and sport of Guilan and the results showed that the factor of internal processes in the department of sport and the youth of Guilan indicates the most of the variations of scorecard balanced in the general directorate of youth and sport which has a loading factor of 0.91 that is consistent with the results of Mosaffa (2014).This factor has four dimensions the regarding their importance are namely the youth organization, process of public and rural sport development, process of the development of legal, professional and athletic sports, parliament and coordination of affairs $(\% 93)(\% 92)(\% 83)$ and $(\% 80)$ of all changes related to the Balanced Scorecard. Although the coefficients of factor loading of all four dimensions were high, two dimensions of organizing youth affairs and process of public and rural sport development with very few differences were more important than other two dimensions. The most important dimension is the organization of youth affairs, which indicates the importance of this dimension. The dimension of organizing youth affairs can be an important challenge for the country that some part of it is investigated at general directorate of youth and sport and executive activities in this area is important for young people. According to Table (1) in the factor of internal processes the public sport development is more important than the development of athletic sport that indicates the importance of this dimension and much attention has been paid by general directorate of youth and sport to public sport than athletic sport in the internal processes regarding the answers of respondents. Also the factor of customer and sportive results in the general directorate of youth and sport of Guilan province has a factor loading of 0.83 . This factor has two dimensions that regarding their importance are namely the results of the athletics and professional sports $(97 \%)$ and the results of public and rural sport $(80 \%)$ can explain all changes that are related to the Balanced Scorecard. Given that the dimension of professional and athletic results is of the utmost importance, or indicates the amount of attention paid on professional and athletic results by managers and experts of general directorate of youth and sport, therefore sport organizations through professional sport can better indicate their position and its positive image in the country. Also in terms of sports results and customer according to the responses of respondents respectively indices of acquired shares in the Olympics, the quota acquired in the Paralympics, earned individual and team ranks in official international events (Olympic and world), invited male and female athletes in different sport fields to national teams, the number of ranks acquired in the individual and team events in Asian, the number of elite athletes in different sports (male and female), the number of different sport fields and the number of gained individual and 
team ranks in national events had the highest importance. In the third part of development and learning in the general directorate of youth and sport of Guilan province has a coefficient factor of 0.81 . This factor has four dimensions that based on their importance, resources, spaces for sports and equipments, environment and communication, education and research explain (78\%), (72\%), (72\%) and (59\%) of all changes related to learning and development. Given that the dimensions of resources and sports spaces and equipments are of the utmost importance, this indicates the importance of this dimension. It means that in order to form an organization first of all human resources, sports spaces and equipment are needed within an organization. Therefore, lack of skilled human resources in organization can lead to the inefficient usage of sports equipments. According to Table (1) in the learning and development factor other indoor and outdoor space per capita regarding the factor of resources, increasing the agreements with other organizations in the field of professional, athletic, championship, educational and public sports regarding the factor of environment and communication, holding coaching and refereeing courses in the country and international level in the province regarding the factor of training and increasing scientific meetings; increasing support for sports research projects in province in the form of master and $\mathrm{PhD}$ thesis are the most important factor regarding the factor of study. Finally, the financial factor of general directorate of youth and sport in Guilan province has factor loading of 0.80 . This factor has two dimensions that regarding to their importance, attracting financial resources and financial management respectively explain the (96\%) and (86\%) of the total changes that are related to financial factor. Given that this factor has upmost importance after absorption of financial resources this indicates that general directorate of youth and sport in Guilan province pays much attention to the attraction of financial resources more than financial management. In financial factors and its strategic indicators based on the responses of respondents, indicators of financial credits of sport and youth department, constructional budget of sport and youth department, the provincial attraction of credit from other sources (cost- capital), the absorption of funds by donors and the amount of income through renting is more than other indices. That indicates the attention of the general directorate of youth and sport of Guilan province to the importance of attracting financial resources and financial management and spending it on relevant topics. Thus, building a budget and codified financial resource in the form of income-generating projects and absorbing governmental and non-governmental financial resources seems necessary for the department of sport and youth. Thus, according to the survey results, it is suggested that in evaluating the performance of the department of sport and youth, more attention should be paid on four above mentioned factors and their dimensions and approved indicators. That based on factor loading the priority of activity and evaluation is dedicated to internal processes, especially two important issues that are related to organizing the youth affairs and rural and public development of sport, regarding the customer perspective and sport results especially on the results of the athletics and professional sports, regarding the factor of development and learning the special attention is on the dimension of resources, regarding sports spaces and the development of sports facilities and finally in the financial factor the special attention is on the financial resources.

\section{Conflict of interests}

The authors declare that there is no conflict of interests.

\section{References}

1. Adams A, Armitage S, Mutuality for football clubs, lessons from the financial sector. Studies in Economics and Finance, 2002;22(1):26-41.

2. Alian Nafisa. Exploring the possibility of implementing balanced scorecard approach for evaluating the performance of general directorate of youth and sport. [PhD thesis]. Isfahan: University of Guilan; 2013.

3. Alonso Angle B, Fernandez Patricio S. The Balanced Scorecard of Investment in Sport: Proposal for Change. Rivista di Diritto ed Economia dello Sport, 2009;1: 1-10.

4. Amiri F. Performance evaluation of organizations through Kanji's Business Excellence Model. Journal of Tadbir. 2006;168:100-110.

5. Asmild M, Paradi JC, Pastor JT. Centralized resource allocation BCC models. Omega. 2009;37: 40-49.

6. Delaney D Daniel. Accounting for Athletics: A Balanced Scorecard Approach. Thesis. University of Connecticut - Storrs. Drive Performance. Harvard Business Review on Measuring Corporate Performance; 2008.

7. Delurgio SA. Forecasting principles and applications. McGrow Hill edition; 1998.

8. Hosseini Misagh. Designing the performance evaluation of football premier league clubs in Iran using the Balanced Scorecard [PhD thesis]. University of Guilan; 2011

9. Kaplan Robert S, David P Norton. Translating Strategy in to Action. Tehran: Published by Irans Commercial Studies and Research Institute; 2006.

10. Kaplan Robert S, Norton David P. Strategy Oriented Organization. Tehran: Publication of Industrial Management Institute. 2007

11. Kaplan RS, Norton DP. Putting the balance scorecard to work. Harvard Business Review. 1993;10:134-147.

12. Kaplan RS, Norton DP. Using the Balanced Scorecard as a strategic. 1996. 
13. Mehrghan MR, Dehghan Mahmoud. Strategic model for the assessment of higher education institutions. Journal of Research and Planning in Higher Education, 2009;52:55-72.

14. Mir Fakhredini Heydar, Peymanfar MH, Khatibi Aghda Abd al-Nabi, Ali-Mohammadi H. Evaluating the performance of sport organizations using an integrated model TOPSIS. BSC (Case Study of Physical Education in Yazd province); 2013.

15. Mosaffa P. Designing a model for evaluating the performance of sport commissions in Guilan Province through balanced scorecard approach [PhD thesis]. Islamic Azad University of Karaj; 2014.

16. Nion Paul R. Balanced Scorecard-step by step guide to design and implementation. Tehran: Publication of Industrial Management Institute; 2007.

17. O'Boyle I. Developing a performance management framework for a national sport organisation. Sport Management Review. 2015;18(2):308316.

18. Parker C. Performance management. Work study, 2000;49(2):63-66.

19. Saadatpour Reza. Evaluating the performance evaluation of employees in Physical education offices in Khorasan Razavi province based on the Balanced Scorecard (BSC). [M.A. thesis]. University of Guilan; 2011.

\begin{tabular}{|c|}
\hline \\
\hline $\begin{array}{l}\text { Hamidreza Goharrostam; Assistant Professor, Faculty of } \\
\text { Physical Education; http://orcid.org/0000-0003-3143-1770; } \\
\text { goharrostami@gmail.com; University of Guilan; P.O. Box 1841 } \\
\text { Rasht, Iran. }\end{array}$ \\
\hline 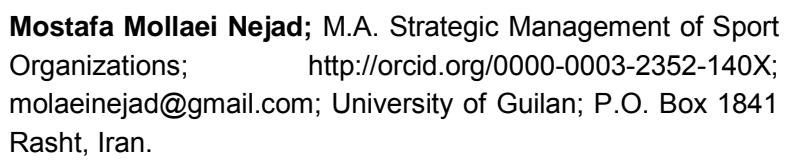 \\
\hline $\begin{array}{l}\text { Rahim Ramezani Nejad; Professor, Faculty of Physical } \\
\begin{array}{ll}\text { Education; } & \text { http://orcid.org/0000-0002-7280-007X; } \\
\text { guilan.ac.ir@gmail.com; University of Guilan; P.O. Box } 1841\end{array}\end{array}$ \\
\hline
\end{tabular}

Rasht,

Cite this article as: Hamidreza Goharrostami, Mustafa Mollaei Nejad, Rahim Ramezani Nejad. Structural equation modeling (SEM) of performance evaluation indices in General Directorate of youth and sport of Guilan Province with partial least squares (PLS). Physical education of students, 2016;5:49-56. doi:10.15561/20755279.2016.0507

The electronic version of this article is the complete one and can be found online at: http://www.sportpedu.org.ua/html/arhive-e.html

This is an Open Access article distributed under the terms of the Creative Commons Attribution License, which permits unrestricted use, distribution, and reproduction in any medium, provided the original work is properly cited (http://creativecommons.org/licenses/by/4.0/deed.en).

Received: 01.10.2016

Accepted: 19.10.2016; Published: 28.10.2016 